\title{
Platyconic Acid A, Platycodi Radix-Derived Saponin, Suppresses TGF- $\beta 1$-Induced Activation of Hepatic Stellate Cells via Blocking SMAD and Activating the PPAR $\gamma$ Signaling Pathway
}

\author{
Jae Ho Choi ${ }^{1}$, Seul Mi Kim ${ }^{1}$, Gi Ho Lee ${ }^{1}$, Sun Woo Jin ${ }^{1}$, Hyun Sun Lee ${ }^{2}$, Young Chul Chung ${ }^{3}$ \\ and Hye Gwang Jeong ${ }^{1, *(\mathbb{D})}$ \\ 1 Department of Toxicology, College of Pharmacy, Chungnam National University, Daejeon 34134, Korea; \\ choijh1@cnu.ac.kr (J.H.C.); sarah5350@naver.com (S.M.K.); ghk1900@cnu.ac.kr (G.H.L.); \\ mpassword@cnu.ac.kr (S.W.J.) \\ 2 Natural Medicine Research Center, Korea Research Institute of Bioscience and Biotechnology, \\ Ochang 28116, Korea; leehs@kribb.re.kr \\ 3 Department of Food and Medicine, College of Public Health and Natural Science, \\ International University of Korea, Jinju 52833, Korea; fnjung@hanmil.net \\ * Correspondence: hgjeong@cnu.ac.kr; Tel.: +82-42-821-5936
}

Received: 21 October 2019; Accepted: 28 November 2019; Published: 29 November 2019

\begin{abstract}
Platycodi radix is a widely sold health food worldwide, which contains numerous phytochemicals that are beneficial to health. Previously, we reported that saponin from the roots of Platycodi radix-derived saponin inhibited toxicant-induced liver diseases. Nevertheless, the inhibitory effect of platyconic acid A (PA), the active component of Platycodi radix-derived saponin, on the anti-fibrotic activity involving the SMAD pathway remains unclear. We investigated the inhibitory effects of PA on TGF- $\beta 1$-induced activation of hepatic stellate cells (HSCs). PA inhibited TGF- $\beta 1$-enhanced cell proliferation, as well as expression of $\alpha$-SMA and collagen I $\alpha 1$ in HSC-T6 cells. PA suppressed TGF- $\beta 1$-induced smad2/3 phosphorylation and smad binding elements 4 (SBE4) luciferase activity. Reversely, PA restored TGF- $\beta 1$-reduced expression of smad7 and peroxisome proliferator-activated receptor (PPAR) $\gamma$. PA also repressed TGF- $\beta 1$-induced phosphorylation of Akt and MAPKs. In summary, the results suggest that the inhibitory effect of PA on HSCs occurs through the blocking of SMAD-dependent and SMAD-independent pathways, leading to the suppression of $\alpha$-SMA and collagen I $\alpha 1$ expression.
\end{abstract}

Keywords: platyconic acid A; TGF- $\beta 1$; hepatic stellate cells; SMAD; PPAR $\gamma$

\section{Introduction}

Liver diseases constitute one of the world's major health problems, causing serious morbidity and mortality [1]. Hepatic fibrosis can progress to liver cirrhosis accompanied by severe liver disease, leading to disorders of normal liver architecture and nodule formation, liver cancer, and ultimately liver failure. Hepatic fibrosis is generally prognostic for chronic liver injury caused by alcoholic abuse, obesity, and viral infection [2]. Although various risk factors have been reported and disease progress has been well studied, the mechanisms of therapeutic targets for various forms of chronic liver disease remain unclear.

Hepatic stellate cells (HSCs), a nonparenchymal cell type within the perisinusoidal space of Disse, contribute to key homeostatic functions of the liver, including regeneration, immunoregulation, drug metabolism, and detoxification. In normal liver, HSCs are stored as non-proliferative, quiescent cells 
with lipid droplets containing retinol [3]. When HSCs are activated, they lose their lipid droplets and differentiate into activated myoblast cells, which express smooth muscle actin and various types of collagen proteins, resulting in extracellular matrix deposition and fibrosis during chronic liver injury [4]. After their activation, growth factors cause the proliferation of HSCs.

Transforming growth factor (TGF)- $\beta$ is a major regulator of physiological and pathological fibrosis. It induces proliferation and migration of HSCs in the liver and is generally well-known as an important therapeutic treatment for fibrotic diseases [5]. The activation of HSCs by the TGF- $\beta$ signal pathway is related to SMAD-dependent and SMAD-independent pathways. Intracellular TGF- $\beta$ signaling is mediated mainly through SMAD-dependent pathways. TGF- $\beta$ signaling is initiated by a ligand that binds to the type 2 TGF- $\beta$ receptor (T $\beta$ RII), which induces type 1 TGF- $\beta$ receptor (T $\beta$ RI) phosphorylation to induce smad 2 and smad 3 phosphorylation, followed by binding to smad 4 to form a complex. The SMAD complex binds to smad binding elements (SBEs) of the gene promoter, followed by translocation to the nucleus where it regulates transcription of the target gene. In contrast, smad7, a negative regulator of the TGF- $\beta 1$ signaling pathway, binds to T $\beta R I$ to block the phosphorylation of smad2/3 [6]. TGF $\beta$ also activates Akt and the mitogen-activated protein kinases (MAPKs) signal pathways, including ERK1/2, JNK1/2, and p38 MAPK, via a SMAD-independent pathway to promote HSCs activation $[7,8]$.

Peroxisome proliferator-activated receptor (PPAR) $\gamma$ is a ligand-dependent nuclear receptor, which modulates the negative role of the profibrotic signaling pathway involving fibrogenesis in liver tissue $[9,10]$. PPAR $\gamma$ blocks the TGF- $\beta$ pathway to suppress myofibroblast transdifferentiation from fibroblasts. Finally, PPAR $\gamma$ inhibits TGF- $\beta$-induced downstream signal transduction and hepatic fibrogenesis [11]. Recent studies have reported that PPAR $\gamma$ is activated by natural and pharmacological agents. These PPAR $\gamma$ agonists prevent TGF- $\beta$-induced smad $2 / 3$ phosphorylation, nuclear accumulation, and recruitment of the smad complex [12]. Therefore, HSCs modulation by SMAD and PPAR $-\gamma$ represents the most relevant therapeutic targets for possible drug treatments of liver fibrosis.

Platycodon grandiflorum A. DC (Campanulaceae) is mainly distributed in Northeast Asia, and has been used as a food resource in the Asian countries of the Korea, Japan, and China [13]. Platycodi radix, the root of P. grandiflorum, is used as in traditional medicine (Chinese name: "Jiegeng;" Japanese name: "Kikyo;" Korean name: "Doraji") [14]. Recently, Platycodi radix, which contains various nutrients (amino acids, trace elements, and unsaturated fatty acids such as linoleic acid), has been considered to be a food source [15]. Our previous studies have reported that aqueous extract and saponin derived from Platycodi radix has protective effects on atopic dermatitis-like skin diseases, airway inflammation, osteoporosis, and metastasis [16-22]. Importantly, we reported that an aqueous extract from Platycodi radix and Platycodi radix-derived saponin inhibited various hepatic toxicant-induced liver diseases via numerous biological and pharmacological effects. For example, Platycodi radix inhibited carbon tetrachloride- and dimethylnitrosamine-induced hepatoxicity, hepatic inflammatory, and fibrogenic markers, including TNF- $\alpha$, COX-2, NF- $\mathrm{kB}, \mathrm{MMP}-13$, TIMP-1, $\alpha$-SMA, and collagen type I via induction of Nrf2-mediated antioxidant enzymes, including $\gamma$-GCS, HO-1, NQO1, and GST $[23,24]$. Platycodi radix-derived saponin also ameliorates high-fat diet-induced nonalcoholic fatty liver diseases and nonalcoholic steatohepatitis symptoms, including hepatic inflammation and fibrogenesis via induction of Nrf2-mediated antioxidant enzymes [25,26]. Notably, Platycodi radix-derived saponin increases the PPAR $\alpha$-regulated fatty acid oxidation markers acyl-CoA oxidase and carnitine-palmitoyl-CoA transferase-1. These results suggest that Platycodi radix-derived saponin reduces hepatic toxicant-induced chronic damage via modulation of antioxidant enzymes.

However, the inhibitory effect of platyconic acid A (PA), the active component of Platycodi radix-derived saponin, on their anti-fibrotic effect remains unclear. Therefore, the objective of this study was to characterize the inhibitory effect of PA on TGF- $\beta 1$-induced activation of HSCs involving the SMAD and PPAR $\gamma$ signal transduction pathways. The results showed that PA decreased hepatic 
fibrogenesis by blocking SMAD and activating PPAR $\gamma$, suggesting that PA could be developed as an alternative treatment for patients with chronic liver fibrosis.

\section{Materials and Methods}

\subsection{Chemicals and Reagents}

The MTT assay kit was purchased from Abcam (ab211091; Cambridge, MA, USA), and the LDH cytotoxicity detection kit was purchased from Roche (04 744926 001; Mannheim, Germany). The WST-1 cell proliferation assay kit (MK400) and RNAiso reagent (9109) were purchased from Takara Bio (Kusatsu, Japan). LY294002, PD98059, SB203580, and SP600125 were purchased from Calbiochem (La Jolla, CA, USA). GW9662 was purchased from Cayman Chemical (Ann Arbor, MI, USA). Lipofectamine ${ }^{\mathrm{TM}} 2000$ transfection reagent was purchased from Invitrogen (11668019; Carlsbad, CA, USA). TGF- $\beta 1$ was purchased from R\&D systems (240-B; Minneapolis, MN, USA). Ethanol (100983) and DMSO (101900) were purchased from Merck (Darmstadt, Germany). Antibodies to the following components were purchased from the following sources: $\alpha$-SMA (M0851; Agilent, CA, USA); collagen I $\alpha 1$ (NB600-408; Novus Biologicals, CO, USA); PPAR $\gamma$ (ABN1445; Merck, Darmstadt, Germany); smad2 (sc-393312), smad3 (sc-101154), smad7 (sc-365846), and $\beta$-actin (sc-47778) (Santa Cruz Biotechnology, CA, USA); p-smad2 (3108), p-smad3 (9520), p-Akt (9271), p-ERK1/2 (9101), p-JNK1/2 (9251), p-p38 MAPK (9211), Akt (9272), ERK1/2 (9102), JNK1/2 (9252), p38 MAPK (9212), and secondary antibodies coupled with horseradish peroxidase (HRP) (anti-rabbit (7404) or anti-mouse (7076) IgG; Cell Signaling Technology, MA, USA). The enhanced chemiluminescence solution was purchased from BIOFACT (OP101-200; Daejeon, Republic of Korea). The Nitrocellulose Membranes membrane was purchased from Amersham Pharmacia Biotech (10600002; Piscataway, NJ, USA). Dulbecco's Modified Eagle's Medium (LM 001-05; DMEM; high glucose), fetal bovine serum (FBS; S 001-07), and penicillin-streptomycin (LS 202-02) solutions were purchased from WELGENE (Gyeongsan, Republic of Korea). All chemicals were of the highest commercially available grade.

\subsection{Preparation of $P A$}

Our previous study reported platyconic acid A (PA) isolation and purification ( $>95 \%)$ from Platycodi radix-derived saponin $[19,27]$. The chemical structure of PA is shown in Figure 1A.

\subsection{Cell Culture}

HSC-T6 cells were cultured in high-glucose DMEM supplemented with 10\% FBS and 1\% penicillin-streptomycin solution. HSC-T6 cells were kept in a humidified atmosphere with $5 \%$ $\mathrm{CO}_{2}$ at $37^{\circ} \mathrm{C}$. Before drug treatment, the cells were changed to serum-free medium overnight. The cells were pretreated with PA for $1 \mathrm{~h}$, treated with TGF- $\beta 1(5 \mathrm{ng} / \mathrm{mL})$ for $24 \mathrm{~h}$, and then harvested for further assays. PA was dissolved in DMSO for all experiments. The final DMSO concentration never exceeded $0.1 \%$, and the solvent had no noticeable effect on the assays.

\subsection{Cell Viability Assay}

The effects of PA on the viability, cytotoxicity, and proliferation of cells were assessed using the MTT, LDH, and WST-1 assay kits according to the manufacturers' instructions.

\subsection{Real Time-Polymerase Chain Reaction}

Total RNA was extracted from PA-treated cells using RNAiso reagent according to the manufacturer's protocol. Accumulated PCR products were detected directly by monitoring the increase in the reporter dye (SYBR; DQ383-40h) signal. The quantity of each transcription was calculated according to the manufacturer's instructions and normalized to the amount of GAPDH as a housekeeping gene. The real time-PCR primer sequences are listed in Table 1. 
A

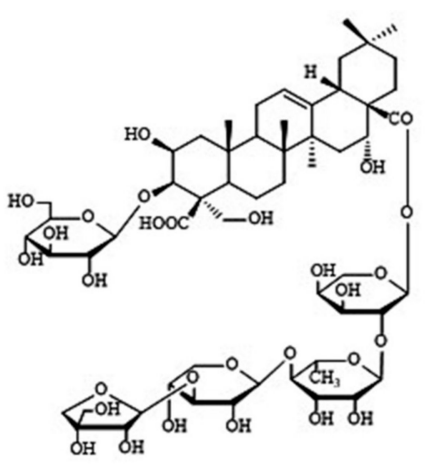

Platyconic acid A (PA)

C

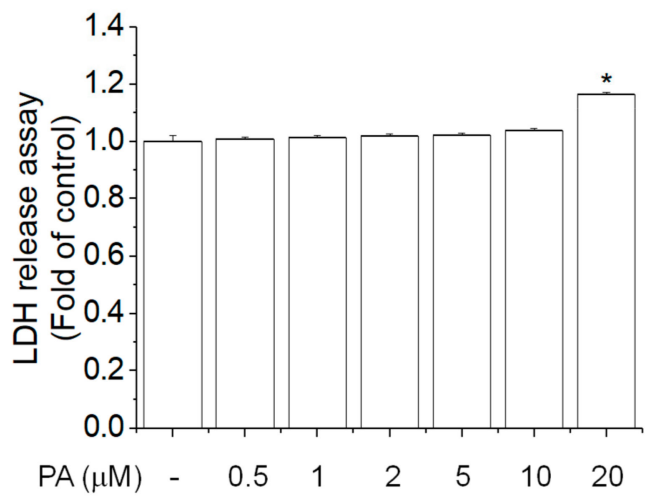

B

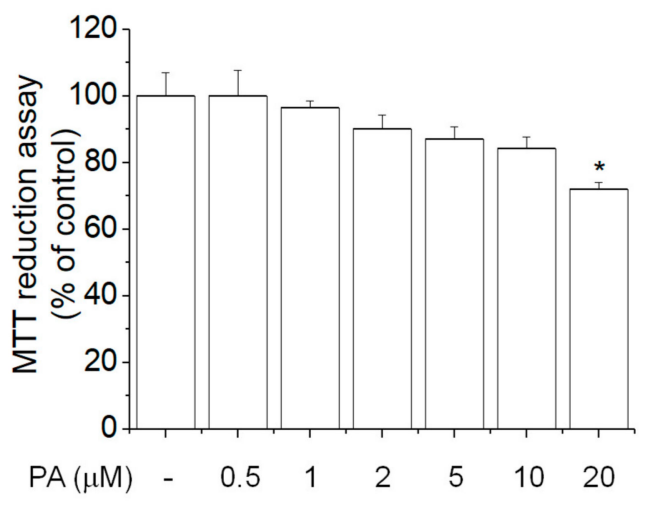

D

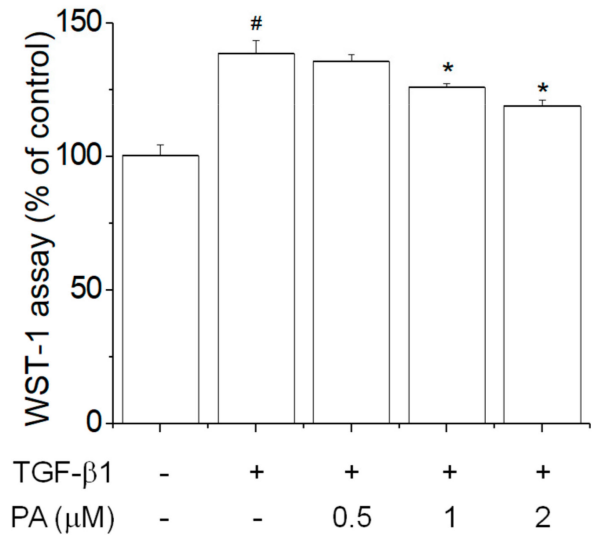

Figure 1. The effects of platyconic acid A (PA) on TGF- $\beta 1$-induced cell proliferation in HSC-T6 cells. (A) The chemical structure of PA; $(B, C)$ the effect of PA on viability and cytotoxicity in rat hepatic stellate cells (HSCs). Cells were treated with various concentrations of PA at $37^{\circ} \mathrm{C}$ for $24 \mathrm{~h}$, and cell viability was determined using the MTT assay, while cell cytotoxicity was analyzed using the LDH assay. The results are expressed as the means \pm SD of three independent experiments. ${ }^{*}$ Significantly different from the control $(p<0.01)$; (D) the inhibitory effect of PA on TGF- $\beta 1$-induced cell proliferation in rat HSCs. Cells were pretreated with $0.5,1$, and $2 \mu \mathrm{M}$ PA for $1 \mathrm{~h}$, and then stimulated with TGF- $\beta 1(5 \mathrm{ng} / \mathrm{mL})$ for $24 \mathrm{~h}$. Cell proliferation was determined using the WST-1 assay. The results are expressed as the means \pm SD of three independent experiments. \# Significantly different from the control $(p<0.01)$. * Significantly different from the TGF- $\beta 1$-treated group $(p<0.01)$.

Table 1. Primer sequences used for the real-time PCR analysis.

\begin{tabular}{ccc}
\hline Gene & \multicolumn{1}{c}{ Forward } & Reverse \\
\hline$\alpha$-SMA & CATCACCAACTGGGACGACA & TCCGTTAGCAAGGTCGGATG \\
ColIa1 & AATCAGCTGGAGTTTCCGTG & TTGGAAACCTTGAGGACCAGG \\
GAPDH & GGCAAGTTCAATGGCACAGT & AAGGTGGAGGAATGGGAGTT \\
\hline
\end{tabular}

\subsection{Luciferase Assay}

Cells were incubated in 24-well plates $\left(5 \times 10^{5}\right.$ cells/well $)$ overnight and transiently co-transfected with smad binding elements 4 (SBE4)-Luc $(0.5 \mu \mathrm{g})$ and pCMV- $\beta$-gal $(0.2 \mu \mathrm{g})$ using Lipofectamine 2000 reagent according to the manufacturer's instructions. After $5 \mathrm{~h}$, the transfection medium was replaced 
with the basal medium. The cells were pretreated with PA for $1 \mathrm{~h}$ and then treated with TGF- $\beta 1$ for $24 \mathrm{~h}$. Luciferase activity was measured using a luminometer (Luminoscan Ascent; Thermo Electron, Langenselbold, Germany), normalized to $\beta$-galactosidase plasmid (\#45964; Addgene, Cambridge, MA, USA), and expressed relative to the luciferase activity of control cells. The SBE4-Luc promoter vector was obtained from Addgene (\#16495; Cambridge, MA, USA).

\subsection{Western Blotting}

The cell lysates were separated by sodium dodecyl sulfate-polyacrylamide gel electrophoresis and transferred to NC membranes, and then incubated with the appropriate primary and HRP-conjugated secondary antibodies. Membranes were visualized using an enhanced chemiluminescence Western blotting detection kit. Protein bands were imaged using densitometry and analyzed using ImageJ software (National Institutes of Health, Bethesda, MD, USA). The relative expression levels of target proteins were normalized using $\beta$-actin as an internal control.

\subsection{Statistical Analysis}

All experiments were performed in triplicate. The results are expressed as the means \pm standard deviation (SD). Statistical significance was determined using one-way analysis of variance followed by the Tukey-Kramer test, with a value of $p<0.01$ indicating significance. A statistical software package (GraphPad Software, San Diego, CA, USA) was used for all statistical calculations.

\section{Results}

\subsection{PA Reduces TGF-B1-Induced HSCs Proliferation}

To examine the inhibitory effects of platyconic acid A (PA) on rat HSCs activation, we examined the cell viability and cell cytotoxic effects of HSC-T6 cells following treatment with various PA concentrations for $24 \mathrm{~h}$. The MTT and LDH assays showed no cytotoxic effects at concentrations $<10$ $\mu \mathrm{MPA}$ (Figure 1B,C). Then, we examined the inhibitory effect of PA on TGF- $\beta 1$-induced cell proliferation using the WST-1 assay, which showed that PA suppressed TGF- $\beta 1$-induced cell proliferation in a concentration-dependent manner (Figure 1D). Based on these results, we selected 0.5, 1, and $2 \mu \mathrm{M} \mathrm{PA}$ concentrations for the subsequent experiments.

\subsection{PA Reduces TGF-B1-Induced HSCs Activation}

Typical features of HSCs activation involve the expression of $\alpha$-SMA and collagen I by TGF- $\beta 1$ [28]. We examined the effects of PA on TGF- $\beta 1$-induced $\alpha$-SMA and collagen I $\alpha 1$ expression in HSC-T6 cells, which showed that PA inhibited TGF- $\beta 1$-induced mRNA and protein expression of $\alpha$-SMA and collagen $I \alpha 1$ in a concentration-dependent manner (Figure 2). These results indicated that PA decreased the TGF- $\beta 1$-induced activation of HSCs via inhibition of transcription and translation.

\subsection{PA Reduces TGF-B1-Induced HSCs Activation by Blocking a SMAD-Dependent Signal Pathway}

TGF- $\beta$ signal transduction involves TGF- $\beta 1$ binding to type II TGF- $\beta$ receptors (T $\beta$ RII), followed by recruitment and activation of type I TGF- $\beta$ receptors (T $\beta$ RI) [29]. Activated T $\beta$ RI phosphorylates smad 2 and smad3, and then forms complexes with smad4, which translocates into the nucleus and binds to smad binding element (SBE) to activate HSCs [6]. To examine the effects of PA on TGF- $\beta 1$-induced phosphorylation of smad 2 and smad3, we first determined the timing of TGF- $\beta 1$-induced phosphorylation of smad 2 and smad 3 in HSC-T6 cells. TGF- $\beta 1$ induced a significant increase in smad 2 and smad 3 phosphorylation at $30 \mathrm{~min}$ (Figure $3 \mathrm{~A}$ ). PA decreased TGF- $\beta 1$-induced phosphorylation of smad2 and smad3 in a concentration-dependent manner (Figure 3B), and PA decreased TGF- $\beta 1$-induced SBE4 luciferase activity in a concentration-dependent manner (Figure 3C). Together, these results indicated that PA reduced TGF- $\beta 1$-induced HSCs activation by suppression of SBE activity via smad2/3 phosphorylation. 

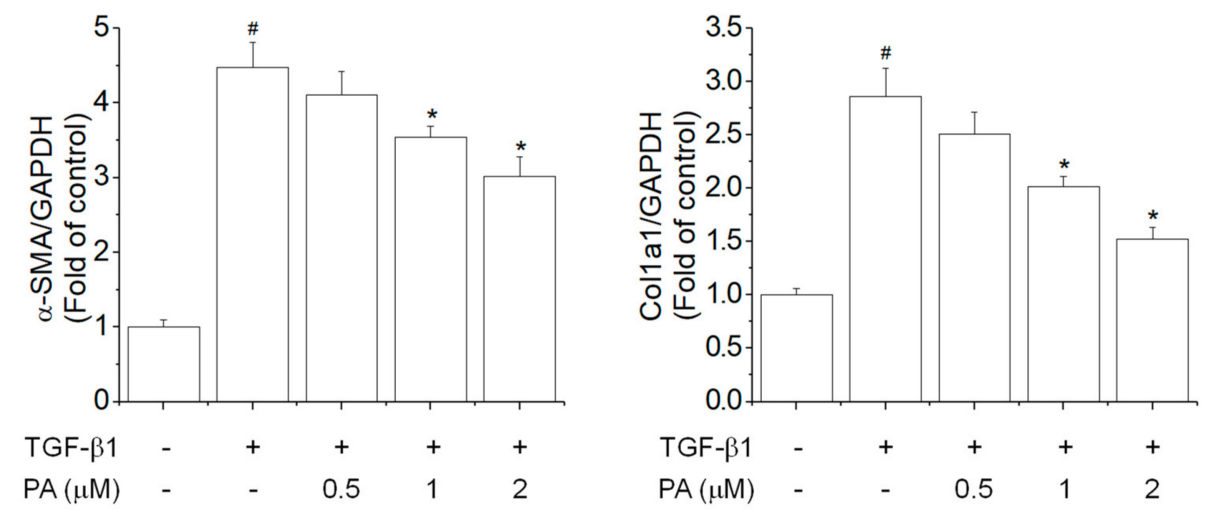

C
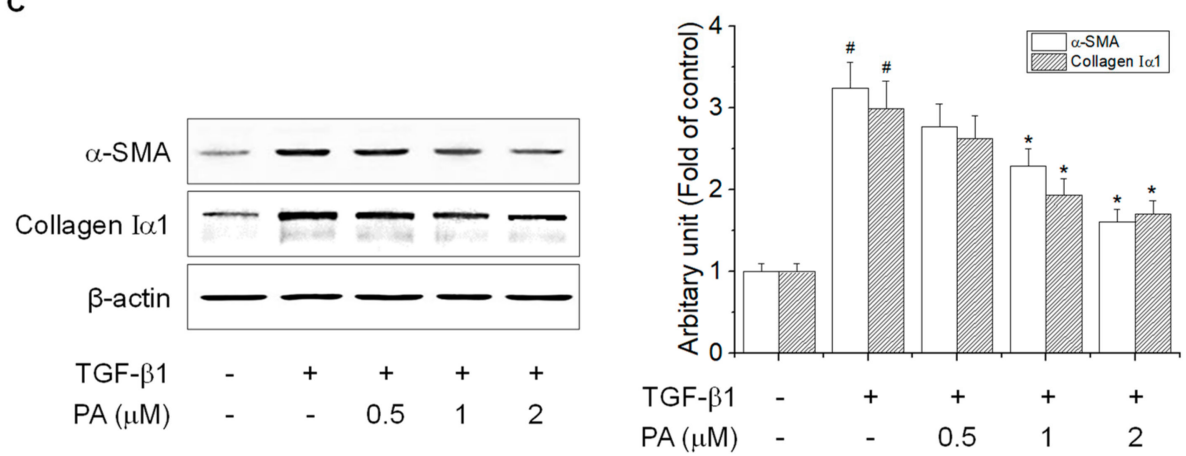

Figure 2. The effects of PA on TGF- $\beta 1$-induced $\alpha$ - SMA and collagen I $\alpha 1$ expression in HSC-T6 cells. $(\mathbf{A}, \mathbf{B})$ The inhibitory effect of PA on TGF- $\beta 1$-induced $\alpha$-SMA and collagen type I mRNA and protein expression in rat hepatic stellate cells. Cells were pretreated with $0.5,1$, and $2 \mu \mathrm{M}$ PA for $1 \mathrm{~h}$, and then stimulated with TGF- $\beta 1(5 \mathrm{ng} / \mathrm{mL})$ for $24 \mathrm{~h}$. Total RNA extracted from cells was analyzed by the real-time polymerase chain reaction to determine $\alpha$-SMA and ColIa1 mRNA expression; (C) the total protein extracted from cells was subjected to Western blotting to determine $\alpha$-SMA and collagen I $\alpha 1$ expression. Protein bands were imaged using densitometry and analyzed using ImageJ software. The relative expression levels of target proteins were normalized using $\beta$-actin as an internal control. The results are expressed as the means \pm SD of three independent experiments. \# Significantly different from the control $(p<0.01)$. Significantly different from the TGF- $\beta 1$-treated group $(p<0.01)$.

In contrast, smad7 acts as a smad inhibitor by inhibiting the TGF- $\beta 1$-dependent SMAD signaling pathway by interfering with smad 2 and smad 3 phosphorylation via T $\beta R I[29,30]$. To examine the effects of PA on TGF- $\beta 1$-reduced smad7 expression, we first determined the timing and concentration of smad7 in HSC-T6 cells. smad7 expression was inhibited by TGF- $\beta 1$ treatment in a time- and concentration-dependent manner (Figure 4A,B). However, PA increased smad7 expression in a timeand concentration-dependent manner (Figure 4C,D). Furthermore, PA restored TGF- $\beta 1$-reduced smad7 expression in a concentration-dependent manner (Figure 4E). Taken together, these results suggested that PA promoted smad7 expression by blocking smad 2 and smad 3 phosphorylation, inhibiting the TGF- $\beta$-dependent SMAD signaling pathway involved in HSC-T6 cell activation. 
A
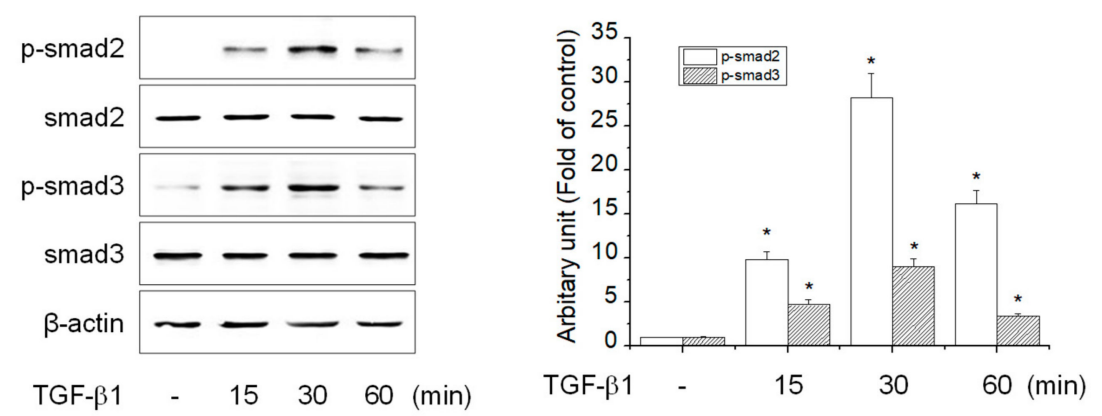

B
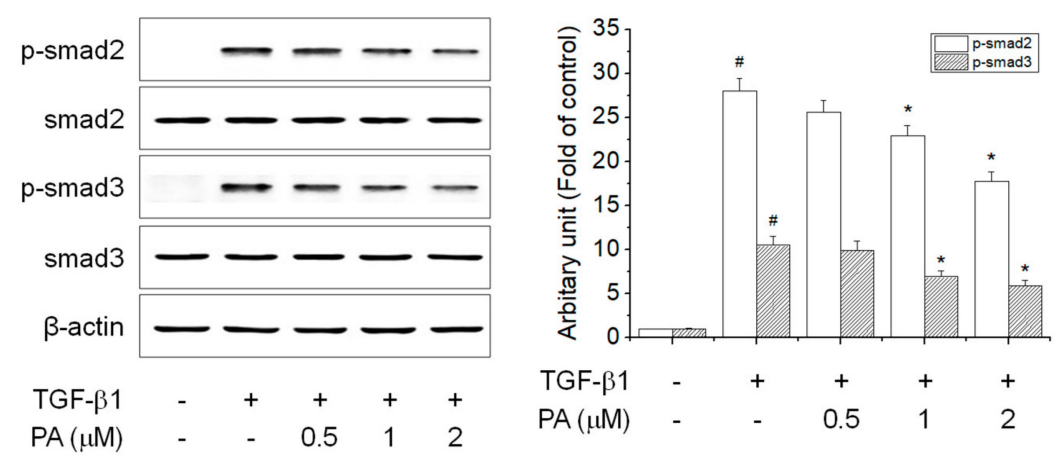

C

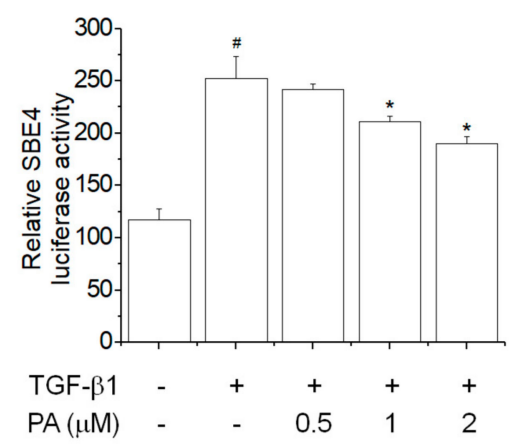

Figure 3. The effects of PA on the TGF- $\beta 1$-induced SMAD signal pathway in HSC-T6 cells. (A) The effect of TGF- $\beta 1$-induced smad 2 and smad 3 phosphorylation in rat hepatic stellate cells (HSCs). Cells were treated with TGF- $\beta 1$ ( $5 \mathrm{ng} / \mathrm{mL})$ for $0,15,30$, and $60 \mathrm{~min}$, and smad 2 and smad 3 phosphorylation was analyzed by Western blotting; (B) the inhibitory effect of PA on TGF- $\beta 1$-induced smad 2 and smad 3 phosphorylation in rat HSCs. Cells were pretreated with $0.5,1$, and $2 \mu \mathrm{M}$ PA for $1 \mathrm{~h}$, and then stimulated with TGF- $\beta 1$ ( $5 \mathrm{ng} / \mathrm{mL}$ ) for $30 \mathrm{~min}$. The total protein extracted from cells was subjected to Western blotting to assess smad 2 and smad 3 phosphorylation. Protein bands were imaged using densitometry and analyzed using ImageJ software. The relative phosphorylation levels of target proteins were normalized using $\beta$-actin as an internal control; (C) the inhibitory effect of PA on TGF- $\beta 1$-induced SBE4 luciferase activity in rat HSCs. Cells were transiently transfected with luciferase reporter containing four copies of the smad binding element sites (SBE4), cultured with PA $(0.5,1$, and $2 \mu \mathrm{M})$ and/or TGF- $\beta 1$ $(5 \mathrm{ng} / \mathrm{mL})$ for $24 \mathrm{~h}$, and the relative luciferase activity in the cell extract was determined. The results are expressed as the means \pm SD of three independent experiments. \# Significantly different from the control $(p<0.01)$. * Significantly different from the TGF- $\beta 1$-treated group $(p<0.01)$. 
A

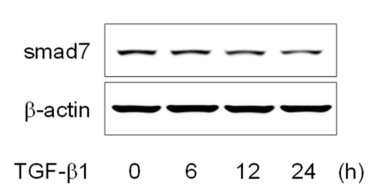

B

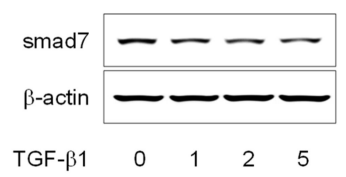

C

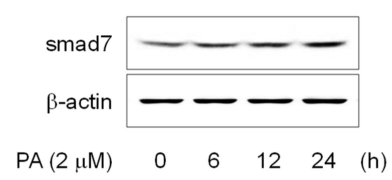

D
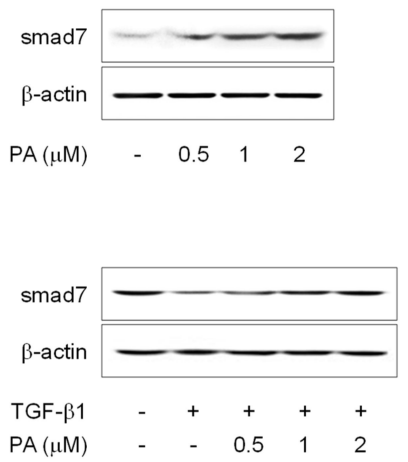
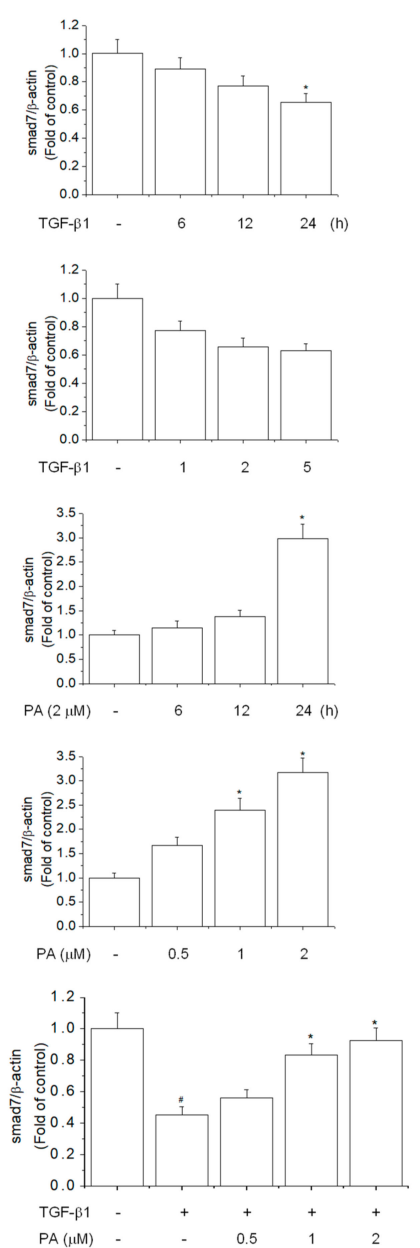

Figure 4. The effects of PA on TGF- $\beta 1$-reduced smad7 expression in HSC-T6 cells. (A,B) The effect of TGF- $\beta 1$-reduced smad7 expression in rat hepatic stellate cells (HSCs). Cells were treated with TGF- $\beta 1$ $(5 \mathrm{ng} / \mathrm{mL})$ for $0,6,12$, and $24 \mathrm{~h}$ or TGF- $\beta 1(1,2$, and $5 \mathrm{ng} / \mathrm{mL})$ for $24 \mathrm{~h}$, and smad7 expression was analyzed by Western blotting; (C,D) the effect of PA-induced smad7 expression in rat HSCs. Cells were treated with PA $(2 \mu \mathrm{M})$ for $0,6,12$, and $24 \mathrm{~h}$ or PA $(0.5,1$, and $2 \mu \mathrm{M})$ for $24 \mathrm{~h}$, and smad7 expression was analyzed by Western blotting; (E) the effect of PA on TGF- $\beta 1$-reduced smad7 expression in rat HSCs. Cells were pretreated with $0.5,1$, and $2 \mu \mathrm{M}$ PA for $1 \mathrm{~h}$, and then stimulated with TGF- $\beta 1(5 \mathrm{ng} / \mathrm{mL})$ for $24 \mathrm{~h}$. The total protein extracted from cells was subjected to Western blotting to determine smad7 expression. Protein bands were imaged using densitometry and analyzed using ImageJ software. The relative expression levels of target proteins were normalized using $\beta$-actin as an internal control. The results are presented as the means \pm SD of three independent experiments. \# Significantly different from the control $(P<0.01)$. ${ }^{*}$ Significantly different from the TGF- $\beta 1$-treated group $(p<0.01)$.

\subsection{PA Reduces TGF- $\beta 1$-Induced HSCs Activation by Upregulation of PPAR $\gamma$}

PPAR $\gamma$ is a key molecular switch that regulates HSCs activation and phenotypic alterations to maintain a quiescent HSCs phase that includes the prevention of the TGF- $\beta 1$ signal, suppression of $\alpha$-SMA, loss of type I collagen, and reduction of cell proliferation [11,31]. Therefore, PPAR $\gamma$ plays an important role in reducing and preventing liver fibrosis via inhibition of HSCs activation. PPAR $\gamma$ is highly expressed in quiescent HSCs, while its expression is decreased during HSCs activation [32]. However, the effect of PA on the mechanism of PPAR $\gamma$ has not been clearly established during HSCs activation. PA treatment resulted in increased PPAR $\gamma$ expression in a time- and concentration-dependent manner (Figure 5A,B) and restored TGF- $\beta 1$-reduced PPAR $\gamma$ expression in a concentration-dependent manner (Figure $5 \mathrm{C}$ ). Together, the results indicated that PA reduced TGF- $\beta 1$-induced HSCs activation by the activation of PPAR $\gamma$. 
A

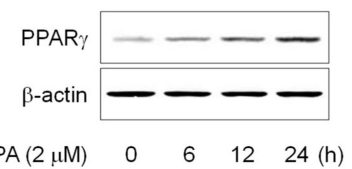

B

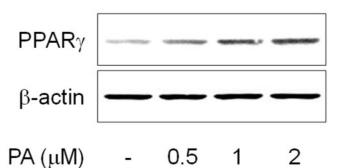

C

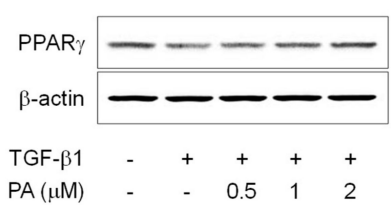

D

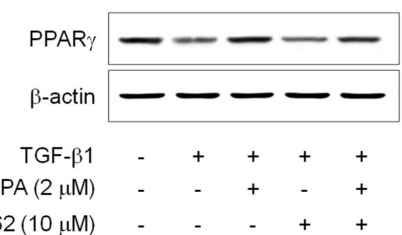

E

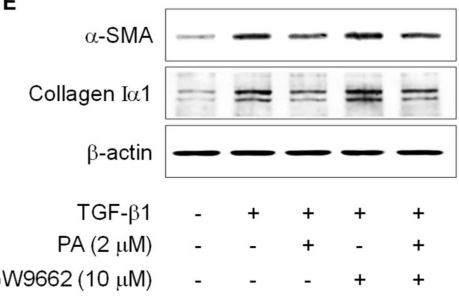

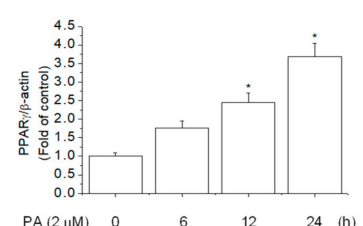

$\begin{array}{llllll}\mathrm{PA}(2 \mu \mathrm{M}) & 0 & 6 & 12 & 24 & \text { (h) }\end{array}$
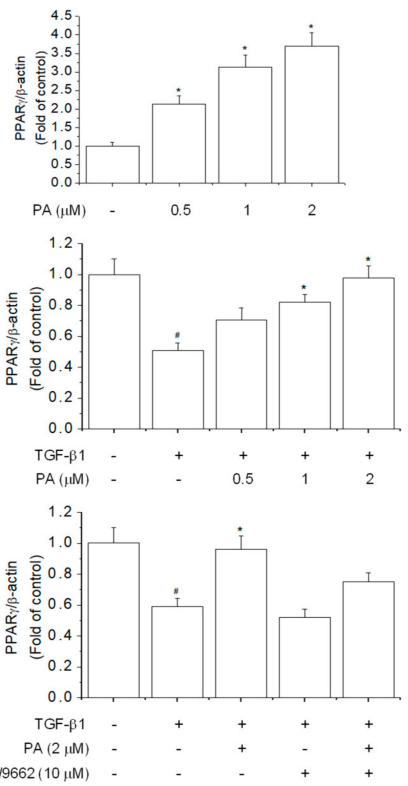

$\operatorname{GW} 9662(10 \mu \mathrm{M})$

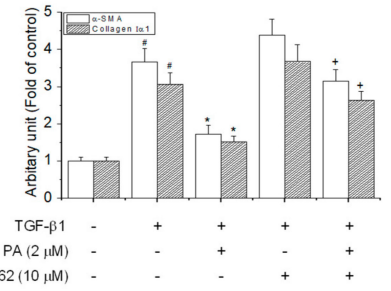

Figure 5. The effects of PA on TGF- $\beta 1$-reduced PPAR $\gamma$ expression in HSC-T6 cells. (A,B) The effect of PA-induced PPAR $\gamma$ expression in rat hepatic stellate cells (HSCs). Cells were treated with PA $(2 \mu \mathrm{M})$ for $0,6,12$, and $24 \mathrm{~h}$ or PA $(0.5,1$, and $2 \mu \mathrm{M})$ for $24 \mathrm{~h}$, and PPAR $\gamma$ expression was analyzed by Western blotting. The effect of PA on TGF- $\beta 1$-reduced PPAR $\gamma$ expression in rat HSCs; (C) cells were pretreated with various concentrations of PA $(0.5,1$, and $2 \mu \mathrm{M})$ for $1 \mathrm{~h}$, and then stimulated with TGF- $\beta 1(5 \mathrm{ng} / \mathrm{mL})$ for $24 \mathrm{~h}$. Total protein extracted from cells was subjected to Western blotting to determine PPAR $\gamma$ expression; (D,E) cells were treated with TGF- $\beta 1(5 \mathrm{ng} / \mathrm{mL})$ for $24 \mathrm{~h}$ in the presence of PA and/or GW9662 $(10 \mu \mathrm{M})$. Total protein extracted from cells was subjected to Western blotting to determine the expression of PPAR $\gamma$ and $\alpha$-SMA and collagen I $\alpha 1$. Protein bands were imaged using densitometry and analyzed using ImageJ software. The relative expression levels of target proteins were normalized using $\beta$-actin as an internal control. The results are presented as the means \pm SD of three independent experiments. \# Significantly different from the control $(p<0.01)$. ${ }^{*}$ Significantly different from the TGF- $\beta 1$-treated group $(p<0.01)$. ${ }^{+}$Significantly different from the PA-treated group $(p<0.01)$.

Studies have reported that the PPAR $\gamma$ antagonist, GW9662, abolished the inhibitory effect of HSC s activation via suppression of $\alpha$-SMA and type I collagen expression [10]. We confirmed the inhibitory effect of PA on TGF- $\beta 1$-induced HSCs activation, which was correlated with an increase of PPAR $\gamma$. PA restored TGF- $\beta 1$-reduced PPAR $\gamma$ expression, which was eliminated by GW9662 (Figure 5D). Furthermore, PA suppression of TGF- $\beta 1$-induced expression of $\alpha$-SMA and collagen I $\alpha 1$ was abrogated by GW9662 (Figure 5E). Together, the results demonstrated that PA suppressed TGF- $\beta 1$-induced HSCs activation by upregulation of PPAR $\gamma$ in HSC-T6 cells 


\subsection{PA Reduces TGF- $\beta 1$-Induced HSCs Activation by Blocking the SMAD-Independent Signal Pathway}

Besides the TGF- $\beta 1$-dependent SMAD pathway, HSCs are activated by a TGF- $\beta 1$-independent non-SMAD pathway, which includes Akt and MAPKs [33,34]. Akt and MAPKs are important mediators of signal transduction involved in the activation of HSCs, which can lead to the regulation of cellular growth, differentiation, and proliferation $[35,36]$. To examine the effects of PA on TGF- $\beta 1$-induced phosphorylation of Akt and MAPKs, we first determined the timing of TGF- $\beta 1$-induced Akt and MAPKs phosphorylation in HSC-T6 cells. TGF- $\beta 1$ induced a significant increase in phosphorylation of Akt, ERK1/2, JNK1/2, and p38 MAPK at 45 min (Figure 6A), which PA diminished in a concentration-dependent manner (Figure 6B).

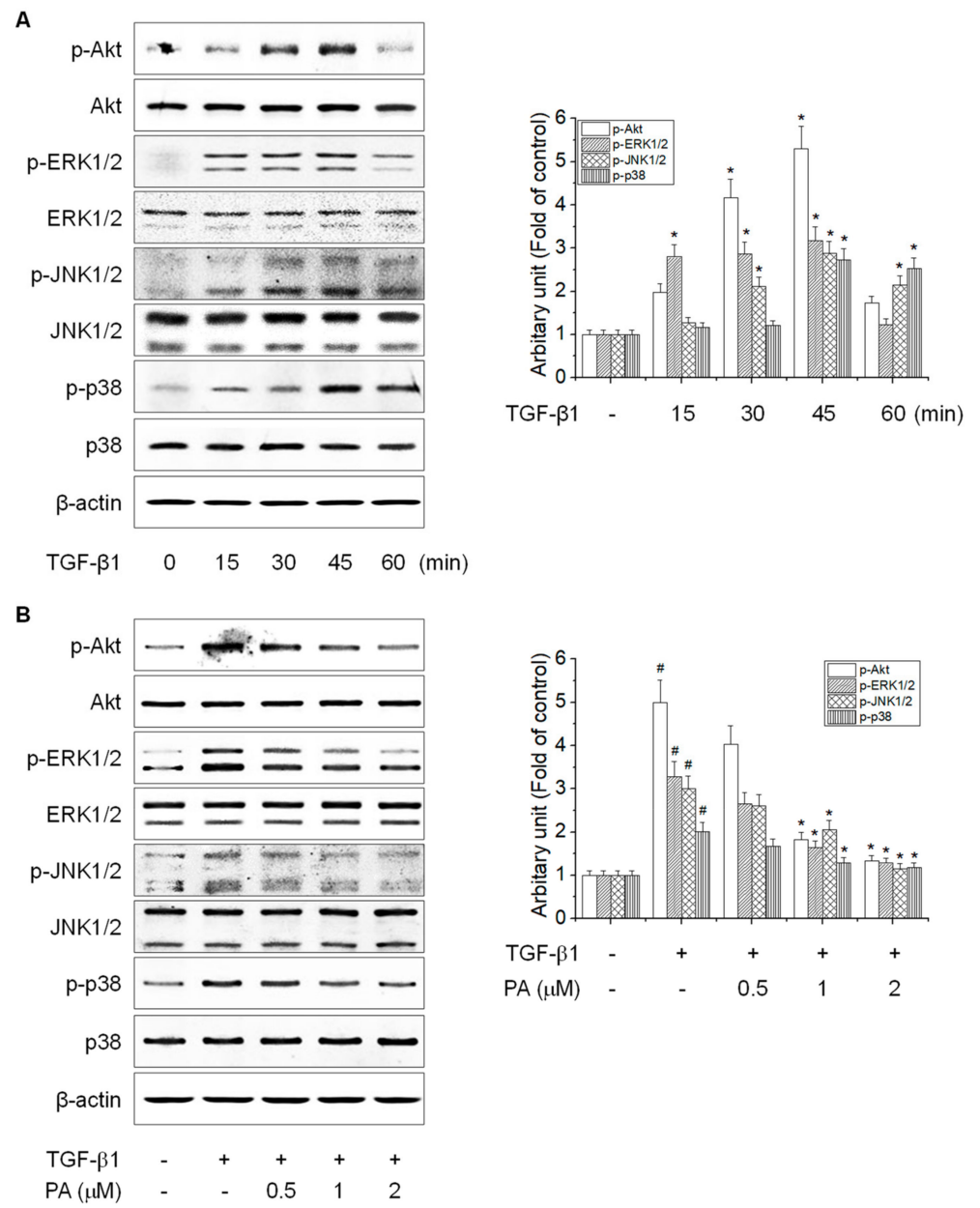

Figure 6. The effects of PA on the TGF- $\beta 1$-induced Akt and MAPK signal pathways in HSC-T6 cells. (A) The effect of TGF- $\beta 1$-induced Akt and MAPKs phosphorylation in rat hepatic stellate cells (HSCs). HSCs were treated with TGF- $\beta 1(5 \mathrm{ng} / \mathrm{mL})$ for $0,15,30,45$, and $60 \mathrm{~min}$, and Akt and MAPKs phosphorylation was analyzed by Western blotting; (B) the inhibitory effect of PA on TGF- $\beta 1$-induced Akt and MAPK phosphorylation in rat HSCs. Cells were pretreated with $0.5,1$, and $2 \mu \mathrm{M}$ PA for $1 \mathrm{~h}$, and then stimulated with TGF- $\beta 1(5 \mathrm{ng} / \mathrm{mL})$ for $45 \mathrm{~min}$. Total protein extracted from cells was subjected to Western blotting to assess Akt, ERK1/2, JNK1/2, and p38 MAPK phosphorylation. Protein bands were imaged using densitometry and analyzed using ImageJ software. The relative phosphorylation levels of target proteins were normalized using $\beta$-actin as an internal control. The results are presented as the means \pm SD of three independent experiments. \# Significantly different from the control $(p<0.01)$. * Significantly different from the TGF- $\beta 1$-treated group $(p<0.01)$. 
Although PA inhibited the phosphorylation of Akt, ERK1/2, JNK1/2, and p38 MAPK, it is necessary to study whether the inhibitory effect of PA on Akt and MAPKs is related the HSCs activation. We confirmed that Akt and MAPKs inhibitors suppressed the TGF- $\beta 1$-induced expression of $\alpha$-SMA and collagen I $\alpha 1$ (Figure 7A). To study which kinases are involved in the inhibitory effect of PA on HSCs activation, we tested the combined treatment with PA and each inhibitor in cells. As shown in Figure 7B, Akt and ERK1/2 inhibitor did not affect PA-mediated inhibition of $\alpha$-SMA and collagen I $\alpha 1$ induced by TGF- $\beta 1$. These results indicated that Akt and ERK1/2 pathways may involve in the inhibitory effect of PA on TGF- $\beta 1$-induced expression of $\alpha$-SMA and collagen $I \alpha 1$ as a non-SMAD pathway.
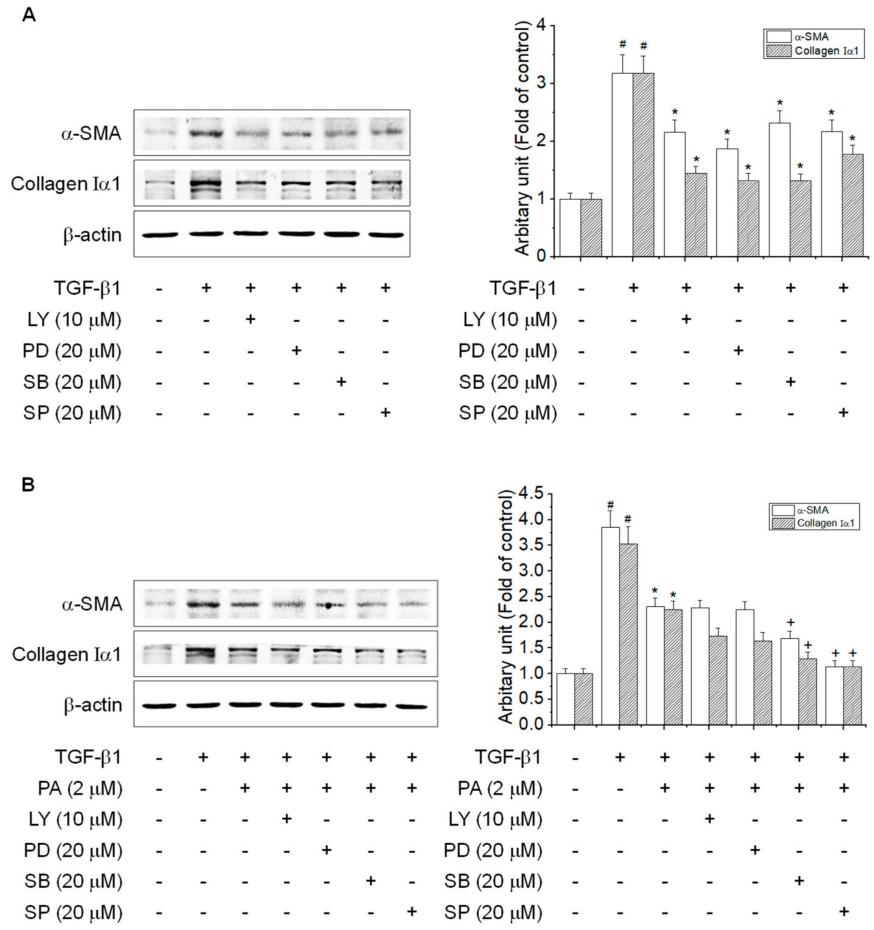

Figure 7. The effects of PA on TGF- $\beta 1$-induced $\alpha$-SMA and collagen I $\alpha 1$ expression via suppression of the Akt and MAPK signal pathways in HSC-T6 cells. (A,B) The inhibitory effects of PA on TGF- $\beta 1$-induced $\alpha$-SMA and collagen I $\alpha 1$ expression via suppression of Akt and MAPK in rat hepatic stellate cells (HSCs); (A) cells were treated with TGF- $\beta 1(5 \mathrm{ng} / \mathrm{mL})$ for $24 \mathrm{~h}$ in the presence of LY294002 (LY; $10 \mu \mathrm{M}$ ), PD98059 (PD; $20 \mu \mathrm{M}$ ), SB203580 (SB; $20 \mu \mathrm{M}$ ), or SP600125 (SP; $20 \mu \mathrm{M})$; (B) cells were treated with TGF- $\beta 1(5 \mathrm{ng} / \mathrm{mL})$ for $24 \mathrm{~h}$ in the presence of PA and LY294002 (LY; $10 \mu \mathrm{M})$, PD98059 (PD; $20 \mu \mathrm{M})$, SB203580 (SB; $20 \mu \mathrm{M})$, or SP600125 (SP; $20 \mu \mathrm{M})$. Total protein extracted from cells was subjected to Western blotting to determine $\alpha$-SMA and collagen $\mathrm{I} \alpha 1$ expression. Protein bands were imaged using densitometry and analyzed using ImageJ software. The relative expression levels of target proteins were normalized using $\beta$-actin as an internal control. The results are presented as the means \pm SD of three independent experiments. \# Significantly different from the control $(p<0.01)$. ${ }^{*}$ Significantly different from the TGF- $\beta 1$-treated group $(p<0.01)$. ${ }^{+}$Significantly different from the PA-treated group $(p<0.01)$.

\section{Discussion}

Liver disease is a major progressive disorder that negatively impacts human health worldwide [37]. Reports have suggested various drugs as protective or inhibitory agents of hepatofibrogenesis, the molecular mechanisms of which have been extensively studied, both in vitro and in vivo [38]. Our previous studies suggested that aqueous extract and saponin derived from Platycodi radix ameliorated various liver diseases, including ethanol-induced alcoholic liver diseases, high-fat diet-induced non-alcoholic fatty liver disease, nonalcoholic steatohepatitis, and carbon tetrachlorideand dimethylnitrosamine-induced liver fibrosis [23-26,39]. However, it has been difficult to determine 
the SMAD-related mechanisms involved in the inhibitory effects of PA, the active component of Platycodi radix-derived saponin, on liver fibrosis during hepatic fibrogenesis. Therefore, we investigated the inhibitory mechanism of PA during HSC activation via SMAD-dependent and SMAD-independent signal pathways by TGF- $\beta 1$ in rat HSC-T6 cells.

Liver fibrosis is the result of chronic liver disease, which involves a complex process associated with excessive hepatocellular damage. The main causes of liver fibrosis, which is characterized by excessive deposition of extracellular matrix (ECM) proteins, are chronic alcoholic ingestion, obesity, and viral hepatitis infection $[40,41]$. Quiescent HSCs are activated and transdifferentiated into cells such as activated myofibroblasts to express SMA and various types of collagen proteins, resulting in ECM deposition during hepatic fibrogenesis. Constant accumulation of collagen causes the liver and vascular structure to be distorted, leading to liver dysfunction, scarring, and liver fibrosis [42]. Therefore, the activation of HSCs during liver fibrosis is an important marker of the initiation of chronic liver disease.

TGF- $\beta 1$, which regulates cell proliferation, differentiation, and ECM formation, is a potent activator of HSCs. When activating HSCs, TGF- $\beta 1$ promotes cell proliferation via increased expression of $\alpha$-SMA and collagen I, leading to excess ECM production and liver fibrosis [30]. Therefore, blocking TGF- $\beta 1$ activity is an effective and logical strategy for preventing or inhibiting liver fibrosis. Our previous studies showed that aqueous extract and saponin derived from Platycodi radix inhibited carbon tetrachloride-, dimethylnitrosamine-, and high-fat diet-induced expression of $\alpha$-SMA and type I collagen in an animal model $[23,24,26]$. In the present study, we confirmed that PA, the active component of Platycodi radix-derived saponin, inhibited TGF- $\beta 1$-induced cell proliferation via suppression of $\alpha$-SMA and collagen Ia1 in a concentration-dependent manner. Notably, PA treatment inhibited $\alpha$-SMA and collagen I $\alpha 1$ expression increased by TGF- $\beta 1$, and simultaneously decreased mRNA and protein expression. These results indicated that inhibition of HSCs by PA is necessary for the inhibition of TGF- $\beta 1$-regulated transcription and translation.

The molecular mechanism of HSCs activation has been shown to involve SMAD-dependent and SMAD-independent signal pathways [43,44]. Importantly, the SMAD pathways have been extensively characterized as the main intracellular signaling pathways of TGF- $\beta 1$. TGF- $\beta 1$ binds to $\mathrm{T} \beta R \mathrm{R}$, followed by subsequent phosphorylation, activation, and complexing with T $\beta$ RII, which results in phosphorylation of smad 2 and smad3. The TGF- $\beta 1$ signal then results in continuous translocation to the nucleus, where it activates HSCs via the upregulation of fibrogenic responses. In contrast, smad7 downregulates the phosphorylation of smad 2 and smad 3 by inhibition of T $\beta R I$ to inhibit the combined binding of smad 2 and smad 3 with the receptors [10]. Our results further showed that PA inhibited TGF- $\beta 1$-induced SBE4 luciferase activity via suppression of smad $2 / 3$ phosphorylation by T $\beta R I$ and T $\beta R I I$ in a concentration-dependent manner. PA also restored TGF- $\beta 1$-reduced smad7 expression. Notably, PA treatment strongly increased smad7 expression in a time- and concentration-dependent manner. These results indicated that PA treatment attenuated the TGF- $\beta$ signal pathway and effectively antagonized the activation of HSCs. PA promoted smad7 expression, blocking smad2 and smad3 phosphorylation, to inhibit the TGF- $\beta$-dependent SMAD signaling pathway involved in HSCs activation.

Recent studies have also reported that TGF- $\beta 1$ stimulates the activation of the Akt and MAPK signaling pathways, which further activate specific transcription factors for specific response elements of profibrogenic markers in HSCs $[45,46]$. The Akt and MAPK pathways, including ERK1/2, JNK1/2, and p38 MAPK, are responsible for the regulation of many cellular functions, including proliferation and apoptosis, which can lead to activation of HSCs. Inhibition of the Akt and MAPK pathways contributes to suppressing HSCs proliferation. Furthermore, our results showed that TGF- $\beta 1$ induced Akt and MAPKs phosphorylation in a TGF- $\beta$-independent signal pathway. PA treatment inhibited phosphorylation of Akt, ERK1/2, JNK1/2, and p38 MAPK by TGF- $\beta 1$-stimulation. However, we confirmed that combined treatment with PA and inhibitor of JNK1/2 or p38 MAPK showed a more pronounced inhibition of expression of $\alpha$-SMA and collagen I $\alpha 1$ induced by TGF- $\beta 1$ than treatment 
with PA alone, but not with the inhibitor of Akt or ERK1/2. These results indicated that Akt and ERK1/2 pathways might be major non-SMAD signal pathways involved in the inhibitory effect of PA on HSCs activation. Nevertheless, further study is needed to clarify how PA regulates Akt and MAPK pathways.

PPAR $\gamma$, as an important nuclear transcription factor, is involved in inhibiting the activation of HSCs, and HSCs activation suppresses the expression and activity of PPAR $\gamma$, both in vitro and in vivo. Enhancement of PPAR $\gamma$ reduced cell proliferation via suppression of $\alpha$-SMA and type I collagen expression by blocking TGF- $\beta 1$ signal transduction in HSCs [31]. In addition, several natural drugs have been shown to increase PPAR $\gamma$-inhibited profibrogenic marker expression stimulated by TGF- $\beta 1$ in HSCs [12]. Our results showed that PA treatment significantly increased PPAR $\gamma$ expression in a time- and concentration-dependent manner. Moreover, we confirmed that the activation of PPAR $\gamma$ might be involved in the inhibition of $\alpha$-SMA and collagen I $\alpha 1$ expression by PA in TGF- $\beta 1$-activated HSCs. These results indicated that PA reduced TGF- $\beta 1$-induced HSC activation through enhancement of PPAR $\gamma$ in HSC-T6 cells.

\section{Conclusions}

In conclusion, the present study provided evidence for the inhibitory effect of platyconic acid A (PA), the active component of Platycodi radix-derived saponin, in rat HSCs. PA inhibited TGF- $\beta 1$-induced HSCs activation through the suppression of SMAD-dependent and SMAD-independent signal transduction pathways (Figure 8). Overall, our results suggest that PA represents a potential candidate for the development of novel chemotherapeutic agents that may contribute to the prevention of liver fibrosis.

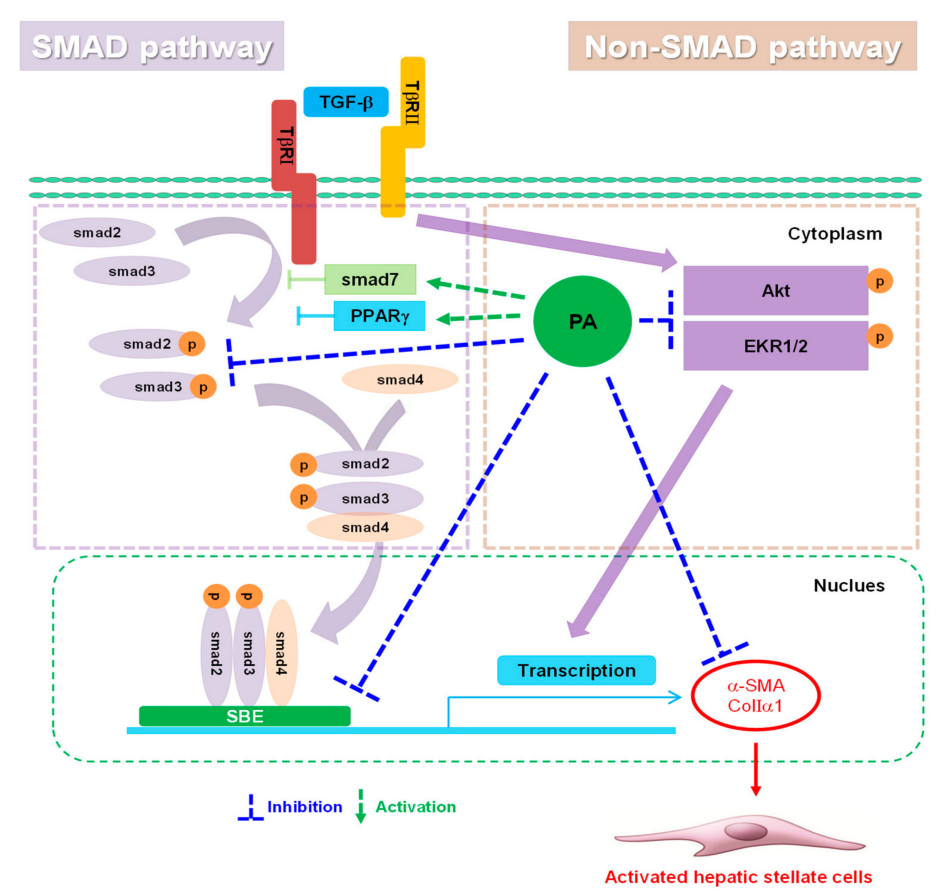

Figure 8. Schematic diagram illustrating the mechanism by which platyconic acid A (PA) inhibits hepatic stellate cell (HSC) activation. PA significantly suppressed $\alpha$-SMA and collagen I $\alpha 1$ expression in rat HSCs by blocking the transforming growth factor (TGF)- $\beta 1$-dependent SMAD signaling pathways and TGF- $\beta 1$-independent non-SMAD signaling pathways. The mechanism of the TGF- $\beta 1$-dependent SMAD signaling pathway involved attenuation of smad $2 / 3$ by enhancing smad 7 and the PPAR $\gamma$. The mechanism of the TGF- $\beta 1$-independent non-SMAD signaling pathway involved inhibition of Akt and ERK1/2. Therefore, PA, the active component of Platycodi radix-derived saponin, is a useful chemotherapeutic agent that may prevent HSCs activation. 
Author Contributions: Conceptualization, supervision, project managing, funding acquisition: H.G.J. Methodology: J.H.C. Data analysis: J.H.C. and S.W.J. Experiments: J.H.C. and S.M.K. Cultures: G.H.L. Figures preparation: J.H.C. Paper writing: J.H.C. Platyconic acid A analysis: H.S.L. Platycodi radix-derived saponin extraction: Y.C.C.

Funding: This work was supported by the National Research Foundation of Korea (NRF) grant funded by the Korea government (MSIP) (No. NRF-2017R1A2B4008966 and NRF-2017R1A4A1015860).

Conflicts of Interest: The authors declare no conflict of interest.

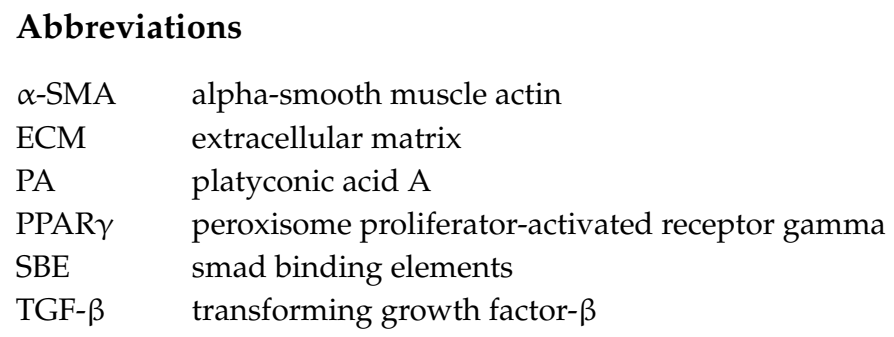

\section{References}

1. Roy, S.; Trautwein, C.; Luedde, T.; Roderburg, C. A General Overview on Non-coding RNA-Based Diagnostic and Therapeutic Approaches for Liver Diseases. Front. Pharmacol. 2018, 9, 805. [CrossRef] [PubMed]

2. Neuman, M.G.; French, S.W.; Zakhari, S.; Malnick, S.; Seitz,H.K.; Cohen, L.B.; Salaspuro, M.; Voinea-Griffin, A.; Barasch, A.; Kirpich, I.A.; et al. Alcohol, microbiome, life style influence alcohol and non-alcoholic organ damage. Exp. Mol. Pathol. 2017, 102, 162-180. [CrossRef] [PubMed]

3. Wallace, M.C.; Friedman, S.L.; Mann, D.A. Emerging and disease-specific mechanisms of hepatic stellate cell activation. Semin. Liver Dis. 2015, 35, 107-118. [CrossRef] [PubMed]

4. Yin, C.; Evason, K.J.; Asahina, K.; Stainier, D.Y. Hepatic stellate cells in liver development, regeneration, and cancer. J. Clin. Investig. 2013, 123, 1902-1910. [CrossRef] [PubMed]

5. Zhou, Y.; Yang, S.; Zhang, P. Effect of Exogenous Fetuin-A on TGF- $\beta /$ Smad Signaling in Hepatic Stellate Cells. Biomed. Res. Int. 2016, 2016, 8462615. [CrossRef] [PubMed]

6. Kim, J.Y.; An, H.J.; Kim, W.H.; Gwon, M.G.; Gu, H.; Park, Y.Y.; Park, K.K. Anti-fibrotic Effects of Synthetic Oligodeoxynucleotide for TGF- $\beta 1$ and Smad in an Animal Model of Liver Cirrhosis. Mol. Ther. Nucleic Acids 2017, 8, 250-263. [CrossRef] [PubMed]

7. Namsen, R.; Rojanasthien, N.; Sireeratawong, S.; Rojsanga, P.; Nimlamool, W.; Potikanond, S. Thunbergia laurifolia Exhibits Antifibrotic Effects in Human Hepatic Stellate Cells. Evid. Based Complement. Alternat. Med. 2017, 2017, 3508569. [CrossRef]

8. Kuo, L.M.; Chen, P.J.; Sung, P.J.; Chang, Y.C.; Ho, C.T.; Wu, Y.H.; Hwang, T.L. The Bioactive Extract of Pinnigorgia sp. Induces Apoptosis of Hepatic Stellate Cells via ROS-ERK/JNK-Caspase-3 Signaling. Mar. Drugs. 2018, 16, 19. [CrossRef]

9. Li, J.F.; Lu, G.F.; Zou, Y.Y. Demethylbellidifolin inhibits proliferation and activation of hepatic stellate cells. J. Investig. Surg. 2011, 24, 171-177. [CrossRef]

10. Choi, J.H.; Jin, S.W.; Choi, C.Y.; Kim, H.G.; Lee, G.H.; Kim, Y.A.; Chung, Y.C.; Jeong, H.G. Capsaicin Inhibits Dimethylnitrosamine-Induced Hepatic Fibrosis by Inhibiting the TGF- $\beta 1 /$ Smad Pathway via Peroxisome Proliferator-Activated Receptor Gamma Activation. J. Agric. Food Chem. 2017, 65, 317-326. [CrossRef]

11. Zhou, D.; Wang, J.; He, L.N.; Li, B.H.; Ding, Y.N.; Chen, Y.W.; Fan, J.G. Prolyl oligopeptidase attenuates hepatic stellate cell activation through induction of Smad7 and PPAR- $\gamma$. Exp. Ther. Med. 2017, 13, 780-786. [CrossRef] [PubMed]

12. Nuwormegbe, S.A.; Sohn, J.H.; Kim, S.W. A PPAR-Gamma Agonist Rosiglitazone Suppresses Fibrotic Response in Human Pterygium Fibroblasts by Modulating the p38 MAPK Pathway. Invest. Ophthalmol. Vis. Sci. 2017, 58, 5217-5226. [CrossRef] [PubMed]

13. Lee, K.J.; Jeong, H.G. Protective effect of Platycodi radix on carbon tetrachloride-induced hepatotoxicity. Food Chem. Toxicol. 2002, 40, 517-525. [CrossRef] 
14. Lee, K.J.; You, H.J.; Park, S.J.; Kim, Y.S.; Chung, Y.C.; Jeong, T.C.; Jeong, H.G. Hepatoprotective effects of Platycodon grandiflorum on acetaminophen-induced liver damage in mice. Cancer Lett. 2001, 174, $73-81$. [CrossRef]

15. Zhang, L.; Wang, Y.; Yang, D.; Zhang, C.; Zhang, N.; Li, M.; Liu, Y. Platycodon grandiflorus-An ethnopharmacological, phytochemical and pharmacological review. J. Ethnopharmacol. 2015, 164, 147-161. [CrossRef] [PubMed]

16. Choi, J.H.; Han, E.H.; Park, B.H.; Kim, H.G.; Hwang, Y.P.; Chung, Y.C.; Lee, Y.C.; Jeong, H.G. Platycodi Radix suppresses development of atopic dermatitis-like skin lesions. Environ. Toxicol. Pharmacol. 2012, 33, 446-452. [CrossRef] [PubMed]

17. Choi, J.H.; Jin, S.W.; Han, E.H.; Park, B.H.; Kim, H.G.; Khanal, T.; Hwang, Y.P.; Do, M.T.; Lee, H.S.; Chung, Y.C.; et al. Platycodon grandiflorum root-derived saponins attenuate atopic dermatitis-like skin lesions via suppression of NF-kB and STAT1 and activation of Nrf2/ARE-mediated heme oxygenase-1. Phytomedicine 2014, 21, 1053-1061. [CrossRef]

18. Choi, J.H.; Hwang, Y.P.; Lee, H.S.; Jeong, H.G. Inhibitory effect of Platycodi Radix on ovalbumin-induced airway inflammation in a murine model of asthma. Food Chem. Toxicol. 2009, 47, 1272-1279. [CrossRef]

19. Choi, J.H.; Jin, S.W.; Kim, H.G.; Choi, C.Y.; Lee, H.S.; Ryu, S.Y.; Chung, Y.C.; Hwang, Y.J.; Um, Y.J.; Jeong, T.C.; et al. Saponins, especially platyconic acid A, from Platycodon grandiflorum reduce airway inflammation in ovalbumin-induced mice and PMA-exposed A549 cells. J. Agric. Food Chem. 2015, 63, 1468-1476. [CrossRef]

20. Jeong, H.M.; Han, E.H.; Jin, Y.H.; Hwang, Y.P.; Kim, H.G.; Park, B.H.; Kim, J.Y.; Chung, Y.C.; Lee, K.Y.; Jeong, H.G. Saponins from the roots of Platycodon grandiflorum stimulate osteoblast differentiation via p38 MAPK- and ERK-dependent RUNX2 activation. Food Chem. Toxicol. 2010, 48, 3362-3368. [CrossRef]

21. Choi, J.H.; Han, Y.; Kim, Y.A.; Jin, S.W.; Lee, G.H.; Jeong, H.M.; Lee, H.S.; Chung, Y.C.; Lee, Y.C.; Kim, E.J.; et al. Platycodin D Inhibits Osteoclastogenesis by Repressing the NFATc1 and MAPK Signaling Pathway. J. Cell. Biochem. 2017, 118, 860-868. [CrossRef] [PubMed]

22. Lee, K.J.; Hwang, S.J.; Choi, J.H.; Jeong, H.G. Saponins derived from the roots of Platycodon grandiflorum inhibit HT-1080 cell invasion and MMPs activities: Regulation of NF-kappaB activation via ROS signal pathway. Cancer Lett. 2008, 268, 233-243. [CrossRef] [PubMed]

23. Lee, K.J.; Kim, J.Y.; Jung, K.S.; Choi, C.Y.; Chung, Y.C.; Kim, D.H.; Jeong, H.G. Suppressive effects of Platycodon grandiflorum on the progress of carbon tetrachloride-induced hepatic fibrosis. Arch. Pharm. Res. 2004, 27, 1238-1244. [CrossRef] [PubMed]

24. Choi, J.H.; Jin, S.W.; Kim, H.G.; Khanal, T.; Hwang, Y.P.; Lee, K.J.; Choi, C.Y.; Chung, Y.C.; Lee, Y.C.; Jeong, H.G. Platycodi Radix attenuates dimethylnitrosamine-induced liver fibrosis in rats by inducing Nrf2-mediated antioxidant enzymes. Food Chem. Toxicol. 2013, 56, 231-239. [CrossRef]

25. Hwang, Y.P.; Choi, J.H.; Kim, H.G.; Khanal, T.; Song, G.Y.; Nam, M.S.; Lee, H.S.; Chung, Y.C.; Lee, Y.C.; Jeong, H.G. Saponins, especially platycodin D, from Platycodon grandiflorum modulate hepatic lipogenesis in high-fat diet-fed rats and high glucose-exposed HepG2 cells. Toxicol. Appl. Pharmacol. 2013, 267, 174-183. [CrossRef]

26. Choi, J.H.; Jin, S.W.; Choi, C.Y.; Kim, H.G.; Kim, S.J.; Lee, H.S.; Chung, Y.C.; Kim, E.J.; Lee, Y.C.; Jeong, H.G. Saponins from the roots of Platycodon grandiflorum ameliorate high fat diet-induced non-alcoholic steatohepatitis. Biomed. Pharmacother. 2017, 86, 205-212. [CrossRef]

27. Choi, Y.H.; Yoo, D.S.; Choi, C.W.; Cha, M.R.; Kim, Y.S.; Lee, H.S.; Lee, K.R.; Ryu, S.Y. Platyconic acid A, a genuine triterpenoid saponin from the roots of Platycodon grandiflorum. Molecules 2008, 13, 2871-2879. [CrossRef]

28. Yang, D.; Li, L.; Qian, S.; Liu, L. Evodiamine ameliorates liver fibrosis in rats via TGF- $\beta 1 /$ Smad signaling pathway. J. Nat. Med. 2018, 72, 145-154. [CrossRef]

29. Hu, Z.; You, P.; Xiong, S.; Gao, J.; Tang, Y.; Ye, X.; Xia, Y.; Zhang, D.; Liu, Y. Carapax Trionycis extracts inhibit fibrogenesis of activated hepatic stellate cells via TGF- $\beta 1 /$ Smad and NFKB signaling. Biomed. Pharmacother. 2017, 95, 11-17. [CrossRef]

30. Yoshida, K.; Matsuzaki, K. Differential Regulation of TGF- $\beta /$ Smad Signaling in Hepatic Stellate Cells between Acute and Chronic Liver Injuries. Front. Physiol. 2012, 3, 53. [CrossRef]

31. Wang, C.Y.; Liu, Q.; Huang, Q.X.; Liu, J.T.; He, Y.H.; Lu, J.J.; Bai, X.Y. Activation of PPAR $\gamma$ is required for hydroxysafflor yellow A of Carthamus tinctorius to attenuate hepatic fibrosis induced by oxidative stress. Phytomedicine 2013, 20, 592-599. [CrossRef] [PubMed] 
32. Lu, L.; Wang, J.; Lu, H.; Zhang, G.; Liu, Y.; Wang, J.; Zhang, Y.; Shang, H.; Ji, H.; Chen, X.; et al. MicroRNA-130a and $-130 \mathrm{~b}$ enhance activation of hepatic stellate cells by suppressing PPAR $\gamma$ expression: A rat fibrosis model study. Biochem. Biophys. Res. Commun. 2015, 465, 387-393. [CrossRef] [PubMed]

33. Jiang, M.; Wu, Y.L.; Li, X.; Zhang, Y.; Xia, K.L.; Cui, B.W.; Lian, L.H.; Nan, J.X. Oligomeric proanthocyanidin derived from grape seeds inhibited NF- $\mathrm{B}$ B signaling in activated HSC: Involvement of JNK/ERK MAPK and PI3K/Akt pathways. Biomed. Pharmacother. 2017, 93, 674-680. [CrossRef] [PubMed]

34. Foo, N.P.; Lin, S.H.; Lee, Y.H.; Wu, M.J.; Wang, Y.J. $\alpha$-Lipoic acid inhibits liver fibrosis through the attenuation of ROS-triggered signaling in hepatic stellate cells activated by PDGF and TGF- $\beta$. Toxicology 2011, 282, $39-46$. [CrossRef]

35. Kuo, L.M.; Kuo, C.Y.; Lin, C.Y.; Hung, M.F.; Shen, J.J.; Hwang, T.L. Intracellular glutathione depletion by oridonin leads to apoptosis in hepatic stellate cells. Molecules 2014, 19, 3327-3344. [CrossRef]

36. Ni, M.M.; Xu, T.; Wang, Y.R.; He, Y.H.; Zhou, Q.; Huang, C.; Meng, X.M.; Li, J. Inhibition of IRF3 expression reduces TGF- $\beta 1$-induced proliferation of hepatic stellate cells. J. Physiol. Biochem. 2016, 72, 9-23. [CrossRef]

37. Higashi, T.; Friedman, S.L.; Hoshida, Y. Hepatic stellate cells as key target in liver fibrosis. Adv. Drug Deliv. Rev. 2017, 121, 27-42. [CrossRef]

38. Schuppan, D.; Ashfaq-Khan, M.; Yang, A.T.; Kim, Y.O. Liver fibrosis: Direct antifibrotic agents and targeted therapies. Matrix Biol. 2018, 68-69, 435-451. [CrossRef]

39. Khanal, T.; Choi, J.H.; Hwang, Y.P.; Chung, Y.C.; Jeong, H.G. Protective effects of saponins from the root of Platycodon grandiflorum against fatty liver in chronic ethanol feeding via the activation of AMP-dependent protein kinase. Food Chem. Toxicol. 2009, 47, 2749-2754. [CrossRef]

40. Greuter, T.; Malhi, H.; Gores, G.J.; Shah, V.H. Therapeutic opportunities for alcoholic steatohepatitis and nonalcoholic steatohepatitis: Exploiting similarities and differences in pathogenesis. JCI Insight 2017, 2, 95354. [CrossRef]

41. Sebastiani, G.; Gkouvatsos, K.; Pantopoulos, K. Chronic hepatitis C and liver fibrosis. World J. Gastroenterol. 2014, 20, 11033-11053. [CrossRef] [PubMed]

42. Tsuchida, T.; Friedman, S.L. Mechanisms of hepatic stellate cell activation. Nat. Rev. Gastroenterol. Hepatol. 2017, 14, 397-411. [CrossRef] [PubMed]

43. Yoshida, K.; Murata, M.; Yamaguchi, T.; Matsuzaki, K. TGF- $\beta / S m a d$ signaling during hepatic fibro-carcinogenesis (review). Int. J. Oncol. 2014, 45, 1363-1371. [CrossRef] [PubMed]

44. Meurer, S.K.; Alsamman, M.; Scholten, D.; Weiskirchen, R. Endoglin in liver fibrogenesis: Bridging basic science and clinical practice. World J. Biol. Chem. 2014, 5, 180-203.

45. Li, J.; Li, X.; Xu, W.; Wang, S.; Hu, Z.; Zhang, Q.; Deng, X.; Wang, J.; Zhang, J.; Guo, C. Antifibrotic effects of luteolin on hepatic stellate cells and liver fibrosis by targeting AKT/mTOR/p70S6K and TGF $\beta / \mathrm{Smad}$ signalling pathways. Liver Int. 2015, 35, 1222-1233. [CrossRef]

46. Zhang, X.; Han, X.; Yin, L.; Xu, L.; Qi, Y.; Xu, Y.; Sun, H.; Lin, Y.; Liu, K.; Peng, J. Potent effects of dioscin against liver fibrosis. Sci. Rep. 2015, 5, 9713. [CrossRef]

(C) 2019 by the authors. Licensee MDPI, Basel, Switzerland. This article is an open access article distributed under the terms and conditions of the Creative Commons Attribution (CC BY) license (http://creativecommons.org/licenses/by/4.0/). 